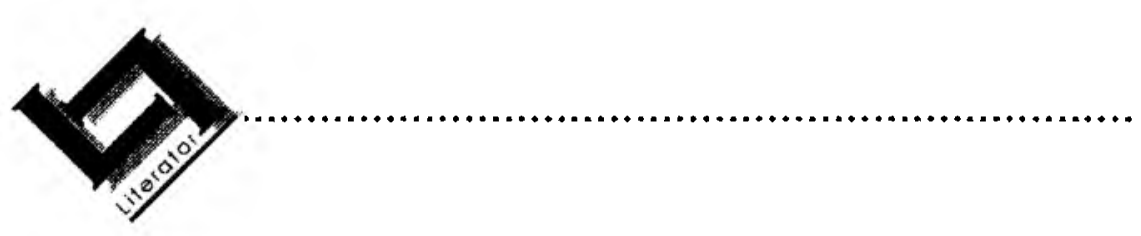

\title{
Tot in die hart van boosheid: twee resente Afrikaanse romans oor die Anglo-Boereoorlog
}

\author{
Luc Renders \\ Vakgroep Talen \\ Limburgs Universitair Centum \\ Diepenbeek \\ België \\ E-pos: luc.renders@luc.ac.be
}

\begin{abstract}
Into the heart of evil: Two recent Afrikaans noveis about the Anglo-Boer War
\end{abstract}

The centenary commemoration of the start of the Anglo-Boer War in 1899 has already inspired the publication of two major Afrikaans novels: Op soek na generaal Mannetjies Mentz by Christoffel Coetzee, and Verliesfontein by Karel Schoeman. These novels should not be considered in isolation. In contemporary Afrikaans literature quite a lot of attention is paid to the Anglo-Boer War. It is, together with the Groot Trek, one of the most significant events in Afrikaner history and has become a very potent symbol of Afrikaner nationalism. The contemporary writer radically debunks the Boer War, thus signifying his absolute rejection of the ideology of the previous generations. This is also the case in $O p$ soek na generaal Mannetjies Mentz and Verliesfontein. Both novels present an unconventional perspective on the war. Op soek na generaal Mannetjies Mentz does not portray a heroic general. On the contrary, Mannetjies Mentz and his commando personify evil. In Verliesfontein the Boer commando not only gave up the village but also all pretence of justice, thereby turning this war episode into their moral Waterloo. Both novels bring a shocking corrective to the traditional representation of the Anglo-Boer War. As a result they destroy the myths on which Afrikaner nationalism has been built and the Afrikaner is forced to look into his own heart of evil. 


\section{Die Anglo-Boereoorlog in die kontemporêre Afrikaanse letterkunde}

\subsection{Blywende belangstelling in die Anglo-Boereoorlog}

In Die Burger van 1 Oktober 1998 waarsku Etienne van Heerden die Afrikanergemeenskap teen die verleiding om die herdenking van die begin van die AngloBoereoorlog 100 jaar gelede met nostalgie te deurdrenk. Die Anglo-Boereoorlog sou inderdaad al te maklik tot hierdie doel kon dien. Die avontuurlike, harde veldlewe, die blinde idealisme van die Boerestryder en die heroïese manhaftigheid waarmee die klein Boerenasies die magtige en wreedaardige Engeland beveg het, lewer buitengewoon aanloklike vertelstof vir 'n romanties-idealiserende bewerking op. Bowendien bevind die Afrikanergemeenskap hom aan die einde van die twintigste eeu weer in 'n soortgelyke posisie as die Boererepublieke 'n eeu gelede. Ook nou moet daar, weliswaar binne 'n totaal ander maatskaplik-politieke konteks, om oorlewing geveg word. 'n Nostalgiese terugreik na die Boereoorlog sou egter beteken dat dieselfde stryd nog steeds gevoer word, wat implisiet 'n ontkenning inhou van die demokratiseringsproses en van die radikaal gewysigde politieke konstellasie in Suid-Afrika.

Van Heerden pleit vir 'n kritiese benadering van die verlede. Hy beskou die Boereoorlog nie net as: "[...] 'n droewe oorlogstorie nie. Dis metafoor vir 'n klomp dinge wat ophoop en saamklos en vra vir lostorring. Dit is ook 'n toetsplek vir hoe ons met ons verlede omgaan; dit is 'n oefening in terugblik en besinning" (Van Heerden, 1998). Hierdie retrospeksie is onlosmaaklik verbind met die hedendaagse realiteit en moet juis daartoe dien om die plek van die Afrikaner binne die nuwe Suid-Afrika te defmieer.

In 1999, 'n eeu na die uitbreek van die Boereoorlog, val die fokus skerp op hierdie gebeure by wyse van herdenkings, seminare, kongresse en van die publikasie van 'n beduidende aantal boeke, versamelbundels en spesiale tydskrifnommers met 'n literêre, wetenskaplike of populêre strekking. Dat ook die Afrikaanse skrywer hom nie onbetuig sal laat nie, is vanselfsprekend. In 1998 het reeds twee belangrike romans oor die Anglo-Boereoorlog verskyn: Op soek na generaal Mannetjies Mentz, die verbluffende debuut van Christoffel Coetzee, en Verliesfontein van Karel Schoeman.

Dis opvallend dat daar, naas die ooglopende verskilpunte, ook baie raakpunte tussen die twee romans is. Een van die betekenisvolste aspekte is dat daar in al twee werke vanuit die hede na die verlede teruggekyk word. Hierdeur groei die relasie tussen hede en verlede, met ander woorde die wyse waarop die verlede vanuit 'n agternaperspektief benader en verwerk word, in albei romans uit tot 'n uiters prominente tematiese gegewe. 
Op soek na generaal Mannetjies Mentz en Verliesfontein moet egter nie in isolasie benader word nie. Dis inderdaad 'n opvallende verskynsel dat in die kontemporêre Afrikaanse literatuur baie aandag aan die Anglo-Boereoorlog gewy word. Dit verbaas 'n mens omdat die Anglo-Boereoorlog in die eerste plek 'n konflik tussen twee blanke groepe was terwyl die stryd teen apartheid blank teenoor swart geplaas het. Die vraag ontstaan onwillekeurig waarom juis die Anglo-Boereoorlog in die kontemporêre Afrikaanse literatuur so belangrik is? Hoe kan hierdie blywende belangstelling verklaar word?

\subsection{Die Anglo-Boereoorlog as burgeroorlog}

Saam met die Groot Trek is die Anglo-Boereoorlog een van die twee mees kritieke episodes uit die geskiedenis van die Afrikanervolk. Albei is onlosmaaklik met mekaar verbind. Deurdat die Engelse die Anglo-Boereoorlog gewen het, word die vryheidstrewe van die Afrikaner, waarvan die Groot Trek die beliggaming is, gefnuik. Dis vanselfsprekend dat die Afrikaners hieroor verontreg gevoel het. Die onreg wat gely is, het die impuls gevorm tot die uitbou van 'n strategie wat die Afrikaner moes toelaat om op alle vlakke van die maatskappy 'n magsposisie te beklee. Om hierdie ideaal te bereik, is lojaliteit aan die eie volk as hoogste eis gestel. Vir 'n groot gedeelte van die twintigste eeu is die Groot Trek en die Anglo-Boereoorlog ingespan om eenheid onder die Afrikanervolk te help bewerkstellig. Die Groot Trek en die Anglo-Boereoorlog simboliseer die aspirasies van die Afrikaner en die magte wat hierdie strewe teenstaan.

Die heropstanding van die Afrikanervolk kry sy voorlopige politieke beslag met die verkiesingsoorwinning van die Nasionale Party in 1948. Maar ook daarna word die herinnering aan die verknegting uit die verlede aangegryp om met alle middele die verworwe magsposisie te regverdig en te verdedig. Die noodsaak om die mag ten alle koste te behou is aan die jonger generasies as 'n absolute prioriteit voorgehou. Die feit dat die Anglo-Boereoorlog verloor is, kry daardeur 'n baie belangrike betekenis: die Afrikaner kan nie toelaat dat iets dergeliks weer gebeur nie. Dit sou tot sy ondergang kan lei. Mag is gelykgestel met oorlewing.

Terwyl baie ouer skrywers verlede en hede beskou teen die agtergrond van die ontvoogdingstryd van die Afrikaner en die verwesenliking van 'n nasionalistiese ideaal, distansieer 'n aantal van die jonger skrywers hulle meer en meer van die geïdealiseerde en gemitologiseerde geskiedenis van hulle volk. In die kontemporêre Afrikaanse literatuur dien die tradisionele denkpatrone dikwels as uitgangspunt vir die verhaalgebeure. In Die jogger van A.P. Brink, Die verlore vader van J.C. Steyn, Die reuk van appels van Mark Behr, en Slegs blankes/ Whites only van Pierre de Vos word aangedui dat die traumas wat die Afrikaner uit die geskiedenis meesleep, gelei het tot die ontsporinge tydens die apartheidsjare. Die ouer generasie gebruik die verlede as argument om hulle huidige 
magsposisie te handhaaf. Vir die jonger generasie is die skynheiligheid en morele onhoudbaarheid van die apartheidsbeleid so vanselfsprekend dat hulle daarteen in opstand kom. Dit hou noodsaaklikerwys afstandname van die verlede in en 'n kritiese besinning oor die manier waarop die Afrikaner die verlede vir eie politieke doeleindes ingespan het. 'n Indringende hersiening van die geskiedenis dring homself dan ook op.

Die jonger generasie verwerp onomwonde die ideologiese lading wat die AngloBoereoorlog dek. Die Anglo-Boereoorlog loop dan ook soos 'n waterskeiding deur die hedendaagse Afrikaanse literatuur. By die jonger generasie skrywers is die behandeling van die Anglo-Boereoorlog een van die belangrikste simbole om hulle afkeer van die ouer generasie en van die ideologie van Afrikanernasionalisme gestalte te gee. Die Anglo-Boereoorlog is nie langer 'n stryd tussen Afrikaner en Engelsman nie of word nie meer aangewend om die Afrikaner te waarsku om laer te trek teen die dreigende swart gevaar nie. Die houding wat in die kontemporêre prosa en drama teenoor die Anglo-Boereoorlog ingeneem word, plaas Afrikaner teenoor Afrikaner, pa en ma teenoor seun en dogter. Die Anglo-Boereoorlog het 'n wig deur die hart van die Afrikanervolk gedryf.

In die hedendaagse Afrikaanse prosa en drama het die Anglo-Boereoorlog 'n sleutelfunksie as gevolg van die bepalende impak daarvan op die ideologie van die Afrikaner. Met die ondermyning van die eensydige voorstelling en die aantoon van die manipulasie van die verlede uit suiwer ideologiese oogmerke, verloor die Anglo-Boereoorlog sy bruikbaarheid as propagandamiddel vir Afrikanernasionalisme. Van wat beskou word as 'n konflik tussen twee blanke stamme, word die Anglo-Boereoorlog die inset van die stryd teen die eksklusief blanke aansprake op en die blanke oorheersing van Suid-Afrika. Op hierdie wyse word die pad na 'n nuwe toekoms oopgeskryf, 'n toekoms wat gesuiwer is van die erflas van die verlede.

Dit is immers alleen deur die radikale afwysing van die ideologie van die voorgeslagte dat harmoniese rasseverhoudinge tot stand kan kom. Dit hou die volledige verwerping van die verlede in. Van die tradisionele Afrikanerdenke word afstand geneem, want net dan word versoening tussen die verskillende rasse moontlik. Die terapie lê in die oopvlekking van die verlede en in die ontmaskering van die ideologiese voorstelling wat daaragter skuil. Eksklusiwiteit moet plek maak vir inklusiwiteit. Die genesing kan bewerkstellig word deur te bieg, deur oop te vlek, deur te suiwer. Nuwe waardes moet die oues vervang. Net wanneer daar na die 'ander' uitgereik word, kan 'n nuwe toekoms ontluik en word die opbou van 'n ander land moontlik.

Sluit ook Christoffel Coetzee se Op soek na generaal Mannetjies Mentz en Karel Schoeman se Verliesfontein by hierdie tendense aan en lewer hulle daarmee 'n bydrae tot die kritiese terugblik waarvoor Etienne van Heerden in sy beskouing in Die Burger 'n lansie breek? 


\section{Op soek na 'n vergete generaal}

\section{1 'n Wit bladsy ingevul}

Op soek na generaal Mannetjies Mentz is waarskynlik die mees opspraakwekkende Afrikaanse prosawerk wat in 1998 verskyn het. Dis 'n merkwaardige debuut. Dit getuig van 'n verbluffende beheer oor die materiaal wat as romanstof gekies is. Die storie gee aan die roman sy onverbiddelike stukrag maar die vertelwyse en veral die fyn hantering van taal sorg vir die intens emosionele impak daarvan.

Die verhaalstof handel oor die Anglo-Boereoorlog. Die historiese agtergrond waarteen die gebeurtenisse hulle afspeel, is die oorgawe van Martiens Prinsloo en 'n groot mag Vrystaatse burgers aan die Engelse generaal Hunter in Junie 1900. Die berge en nekke van die Brandwaterkom in die Oos-Vrystaat vorm die dekor vir die romangebeure.

Die boek bestaan uit vier afdelings. Die eerste is ' $n$ inleiding deur die redakteur, 'n amateurhistorikus wat die opset van sy boek verduidelik. Sy werk is die resultaat van sy ondersoek na die oorlogsaktiwiteite van generaal Mannetjies Mentz en sy kommando, 'n ongedokumenteerde bladsy uit die geskiedenis van die Anglo-Boereoorlog. Dit word gevolg deur drie getuieverslae. Die eerste verslag is die geredigeerde weergawe van die op band opgenome verhaal van Ounooi. Sy het as dogtertjie van twaalf die oorlog meegemaak vanuit die Skuiltes, bergoorhange waar die Naudé-familie 'n veilige heenkome gesoek het. Die tweede getuie is haar broer Frans, wat 'n lid van die kommando van Mannetjies Mentz was. Hy rig 'i: kriftelike verslag van sy oorlogswedervaringe aan Ounooi. Sy verhaal, wat afg'wissel word met nooit gestuurde briewe aan sy suster, vul die leemtes uit Ounooi se relaas aan. Verder beskryf hy hoe Mannetjies Mentz met die kern van sy kommando ná die Vrede van Vereeniging in Oos-Afrika 'n nuwe lewe begin. Ten slotte is daar ' $n$ rapport van generaal Coen Brits wat tydens die Eerste Wêreldoorlog onder Engelse vlag in OosAfrika kampanje voer teen die Duitsers. Brits berig oor 'n besoek aan die plaas van Mannetjies Mentz aan die voet van Kilimanjaro. Die roman lewer dus in die eerste plek verslag van die kontak tussen enersyds die Naudé-familie en andersyds Mannetjies Mentz en sy kommando.

In die inleiding benadruk die redakteur dat sy ondersoek na die bestaan van Mannetjies Mentz 'n soliede basis het, ondanks die feit dat hy byna uitsluitlik op mondelinge oorlewering moes staatmaak. Hy beskou homself as ' $n$ volwaardige historikus en gee aan sy ondersoek die status van 'n wetenskaplike verslag. Boonop moet die oorvloedige aantekeninge en die verwysings na historiese figure en gebeure die lewe van Mannetjies Mentz binne 'n werklikheidskader situeer. Hy wys tewens op die bestaan van "onafhanklike dokumentasie" (22). 
Ondanks al sy pogings lewer sy navorsing nie 'n geheelbeeld op nie maar net 'n fragmentariese blik. Uiteindelik kom die redakteur tot die volgende konklusie: "Wat ons wel met 'n redelike mate van sekerheid te wete kan kom van die persoon wat Mannetjies Mentz sou kon heet, is geisoleerde insidente wat strek oor die loop van sestien, sewentien jaar. Dit is dikwels deur afstand en tyd verder gefragmenteer. Meermale is dit of uit verband geruk of onderdruk as gevolg van persoonlike swakhede wat onder skuld en verwyt skuilgaan. Dit alles, ook persoonlike verwyte en skuld, is deel van ons onvolledige storie oor Mannetjies Mentz" (28). Wat die leser onder oë kry, word nie as 'n roman aangebied nie maar as 'n geskiedkundige werk waarvan die outeur oortuig is dat dit wetenskaplike meriete het.

Volgens die outeur vul sy werk daarbenewens 'n leemte in die offisiële geskiedskrywing waarin niks oor Mannetjies Mentz vermeld word nie. Hoekom het professionele historici nooit enige belangstelling vir Mannetjies Mentz getoon nie en word dit aan 'n verkoopsman oorgelaat om hierdie belangrike navorsing te doen? Die redakteur suggereer dat Mannetjies Mentz doelbewus uit die geskiedenis geskryf is omdat hy nie gepas het binne die ideologiese raamwerk van die Afrikaner en die doeleindes waarvoor die Anglo-Boereoorlog in die eerste helfte van die twintigste eeu gebruik is nie. Mannetjies Mentz het, volgens die outeur, 'n verleentheid geword en moes van die oorlogstoneel verdwyn. In hierdie aantyging lê ' $n$ baie sterk beskuldiging oor die gebruik van die geskiedenis binne Afrikanergeledere met die oog op die verwesenliking van politieke doeleindes.

Die meesternarratief van die geskiedenis het sy geldigheid verloor. Op soek na generaal Mannetjies Mentz beskryf dié geskiedenis wat nie in die offisiële geskiedskrywing teruggevind kan word nie. Dis 'n alternatiewe geskiedenis wat nie een algemeen aanvaarde en absolute waarheid of verhaal propageer nie. Al die betrokkenes het immers hulle eie persoonlike perspektief op die AngloBoereoorlog. Boonop is twee van die persone wat in hierdie roman aan die woord is getuies wat direk beinvloed is deur wat gebeur het en vertel hulle hul verhaal eers jare na die afloop daarvan. Hierdeur word die subjektiewe element natuurlik nog verder verhoog:

Ek dink: Dié is net 'n oorgroeide spoor. 'n Spoor waarvan? Nee, nie eens van insidente nie, want waarvan ek hier praat, is in 'n ou man se verwarde gedagtes. lemand anders sal dié storie ook moet vertel om geloofwaardigheid daaraan te gee; die storie kan nie net teer op herinnering wat dit plooi na die eise van die hede nie (185).

Die redakteur plaas die drie getuieverslae sonder verdere kommentaar langs mekaar. Hulle is nie tot 'n sluitende geheel verwerk nie sodat die leser verplig is om sy eie konklusies te trek. 
Die getuienisse van Ounooi en haar broer, "Blink" Frans, staan sentraal. Ounooi vertel die verhaal van die Naudé-familie se oorlewingstryd tydens die AngloBoereoorlog. Die Naudés word gehelp deur Jan Witsie en sy mense, 'n groep swartes waarmee hulle al jare lank vriendskapsbande gehad het. Die ma heers, in afwesigheid van die manlike familielede wat by die Boeremagte aangesluit het, soos 'n onversetlike martriarg oor hierdie klein gemeenskap. Haar woord is wet. Die oorlog maak van haar 'n skisofrene persoon. Sy is met haar religieuse en politieke fanatisme voorstander van 'n uiters onverbiddelike optrede teen die Engelse sodat sy totaal blind is vir die wandade in eie kring. As gevolg hiervan keer die dogters hulle van die ma af, soos ook die pa sal doen nadat hy uit ballingskap teruggekeer het. Die oorlog ontwikkel sodoende tot ' $n$ interne familiestryd. Dis inderdaad nie die Engelse wat die kommando van Mannetjies Mentz uit die berge verdryf nie, maar Soph wat regstreeks teenoor Mannetjies Mentz en haar broer Frans te staan kom. Dit lei onvermydelik tot 'n onoorbrugbare verdeeldheid binne die Naudé-familie.

Nêrens word trouens van 'n geregverdigde oorlog gepraat nie. Die interne verdeeldheid binne die Afrikanergeledere op grond van die hensoppers en die hanskakies, en die lafhartigheid van die Boerevegters - selfs van die Boeregeneraals - word genadeloos belig. Ook die gruweldade wat deur die kommando van Mannetjies Mentz gepleeg word, word oopgevlek. Sowel die Engelse as die Boere wat nie verder wil veg nie word wreedaardig om die lewe gebring. Dis wreedhede waarvoor daar geen naam is nie en wat ook geen doel dien nie. Inteendeel, daar is 'n suggestie dat die oorlog juis hierdeur nodeloos uitgerek word. Hierdie onvoorstelbare gruwelikhede word in die verslag van Frans, wat self daaraan deelgeneem het, tot in die kleinste besonderhede beskryf. Frans benadruk die gegewe dat die kommando as kollektief optree. Die individu is ondergeskik aan die geheel. Die kommando het sy eie kodes wat dit buite die gewone lewe en selfs buite die algemeen aanvaarde oorlogkonvensies plaas. Hulle wil tot die bitter einde die stryd teen die Engelse verder voer, ongeag die gevolge. Aan hierdie strewe word alles ondergeskik gestel. Die doel heilig die gebruik van die mees barbaarse middele.

Die roman belig nie net die interne verdeeldheid van die Afrikaners en die gruweldade van die Boerekommando nie. Ook ander mites word ontkrag. Die deksel word van die doofpot gehaal. Die beskrywing van die goeie verstandhouding tussen die Naudés en die Witsies, van die liefde tussen 'n Engelse offisier en 'n Afrikanervrou midde-in die oorlogsgeweld en van die misbruik van swart vrouens deur lede van die kommando lei tot 'n verkrummeling van die fondamente van Afrikanernasionalisme, wat 'n eksklusiewe stambewussyn predik. Christoffel Coetzee laat nie een heilige koei in verband met die Anglo-Boereoorlog onaangeraak nie. Die oorlog word volledig gediskrediteer. Hierdeur word die wit plek tot een van die swartste bladsye uit die geskiedenis van die Afrikanervolk gemaak. 


\subsection{Roman en waarheid}

In die oë van die amateurhistorikus het sy boek die status van 'n wetenskaplike teks. Tog is dit vir die leser baie duidelik dat $O p$ soek na generaal Mannetjies Mentz 'n historiese roman is. Die inhoud berus egter nie op historiese feitemateriaal nie. Coetzee self sê hieroor in 'n onderhoud: "Genl. Mentz is 'n verdigsel en die inleiding is twak. Daar is g'n sulke nagelate dokumente nie. Dis alles deel van die spel met die leser" (Rautenbach, 1998). Deur hierdie fiksionalisering eis die skrywer sy aandeel op in die soeke na die waarheid. In hierdie proses gebruik Christoffel Coetzee fiksie as werktuig. Sy soektog na Mannetjies Mentz is skyngeskiedenis omdat dit 'n maaksel van die skrywer is. Juis die estetiserende aanpak - die taal is amper te mooi, te literêr vir die onderwerp wat behandel word - hou die leser deurentyd bewus van die feit dat 'n woordkunstenaar hier aan die werk is. As geskiedenis is die roman ongeloofwaardig, as fiksie daarenteen heeltemal oortuigend. Dit wys daarop dat die rol van die skrywer in die proses van die soeke na die waarheid nog lank nie uitgedien is nie. Die literatuur verkry die funksie van die Waarheids- en Versoeningskommissie: net deur die waarheid aan die lig te bring, kan versoening in die vooruitsig gestel word. Dis trouens in hierdie terme wat Ounooi Frans aanmoedig om sy wandade te bieg: "Frans, kry dié ding uit jou kop en van jou gewete af. Wat het aan julle kant in die berge gebeur, en wat was jou aandeel daaraan? Net dán sal jy vrede met jouself maak" (149). Frans se weergawe kan inderdaad as 'n vorm van skuldbelydenis beskou word. Dit bevestig die relevansie van Op soek na generaal Mannetjies Mentz vir die hede, wat trouens deur die verwysing na "reconciliation en nation-building" (259) nog meer benadruk word.

Naas die blootlegging van die kommando se wreedheid blyk die belangrikste implisiete aanklag te wees dat Mannetjies Mentz en sy kommando nooit vir hulle wandade verantwoording moes doen nie en selfs deur die hoogste instansies beskerm is. Om opnuut te ontken en te swyg oor wat tydens die apartheidsperiode gebeur het, sou heeltemal ontoelaatbaar wees. Coetzee laat homself hieroor uit: "Ek wil hê die leser moet verbande deurtrek van dié oorlog na die huidige gelieg en gebieg. Die WVK het die nuwe leuens en waarhede na vore laat kom" (Nieuwoudt, 1998).

Coetzee belig egter nie net die Anglo-Boereoorlog nie. Sy roman is ook 'n ondersoek na die bose in die mens en in die maatskappy tydens oorlogsomstandighede. Die motto, 'n aanhaling uit die slot van die boek, lui soos volg: "Ek dink: Wat sal dié ongelukkige man só jaag? Is sy skuld en pyn dan soveel erger as ons s'n? En ken ons generaal Mentz nou?" Inderdaad - die getuieverslae oor generaal Mannetjies Mentz het nie juis baie informasie oor hom opgelewer nie. Die verhale wat vertel word, handel nie soseer oor Mannetjies Mentz nie as oor sy invloed op ander mense. Mannetjies Mentz bly deurgaans 
anoniem; hy dwing die ander steeds tot 'n keuse tussen die smal en die breë pad.

'n Mens merk hom nie eers op nie:

Wat ek van hom onthou, is dat hy só doodgewoon was, nie oud nie en nie besonder jonk nie, 'n eerste grys haar in sy stoppelbaard en 'n kortgeknipte militêre snor. [...] Hy is die soort man by wie jy in die straat sal verbystap en juis dit sal die straat vir jou 'n veilige plek maak (59).

Hy bly dwarsdeur die roman 'n figuur op die agtergrond wat niemand leer ken nie. Hy is die voorstelling van die absolute bose. Sy rug vol sweep- of sambokstrepe wat voortdurend begin sweer en onmenslike pyne veroorsaak, lyk na die fisiese teken van hierdie boosheid: "Ek weet dat die kwaad by die geringste koors weer onder so 'n vel uitbreek" (298). Mentz tree amper nooit aktief op nie. Juis daardeur word hy verhef tot die verteenwoordiger van die moontlikheid tot die bose in elke mens en meer in die besonder van die boosheid wat deur oorlogsomstandighede in die mens losgewoel word. Die voorstelling van Mentz en sy twee adjudante as twee honde en 'n jakkals, 'n drekgod, wat onkwesbaar is, sluit hierby aan. Voss en Niemann het dan ook niks mensliks meer nie. Hulle is die uitvoerders van die kwaad. Voss is die slu manipuleerder, Niemann die totaal gewetenlose uitvoerder. Ook al die ander lede van die kommando is in meerdere of mindere mate instrumente in die hande van die bose. Van hierdie bose gaan ook 'n sterk erotiese aantrekkingskrag uit. Deur aan die bose 'n universele dimensie te verleen, strek die romanproblematiek verder as die grense van die Anglo-Boereoorlog om 'n algemeen-menslike ervaring te vertolk.

Dit beteken egter nie dat die roman volmaak is nie. Mens sou kon verwys na die plek-plek onnodige mistifikasies, die oorbodige filosofiese dele, die oordadige woordrykheid, die perspektiefverbrekings, veral in die verhaal van Ounooi, die té opvallende naamgewing en die té opsigtelike allegoriese gedeelte. Teen die einde verloor die roman sy gevatheid. Dit alles verhinder nie dat $O p$ soek na generaal Mannetjies Mentz deur die onverbiddelike stukrag van die storie, die besondere stilistiese vaardigheid en die vernuftige opbou 'n literêre meesterwerk is nie. Boonop is die roman deur die radikale ondergrawing van die populêre Afrikanerdenke, die kritiek op die manipulasie van die geskiedenis vir ideologiese doeleindes en die voorstelling van die onvoorstelbare wreedheid van die mens in oorlogstyd 'n belangwekkende tydsdokument.

\section{Verliesfontein, die Waterloo van die Boere}

\subsection{Op soek na 'n verlore tydperk}

Soos die titel reeds suggereer, sal Karel Schoeman in Verliesfontein nie 'n triomfantlike voorstelling van die Boereoorlog skets nie. Die keuse van die titel "Verliesfontein" voorspel uit die staanspoor weinig wat positief is. Op die eerste 
bladsy word hierdie indruk klaar versterk deur die verwysing na die feit dat 'n nederlaag teen die Boesmans die oorsprong van die betrokke plaas se naam is. Later sal die dorp Fouriesfontein daar opgerig word.

Ook in Verliesfontein word vanuit die hede na die verlede teruggekyk. Juis die kloof tussen hede en verlede vorm die vertrekpunt vir die roman: "Die verlede is 'n ander land: waar is die pad wat soontoe loop?" (7). Die eerste afdeling "Fouriesfontein" bied vervolgens 'n essayistiese besinning oor hierdie vraag. Selfs al is daar maar karige feitelike gegewens, stel sy verbeelding die skrywer in staat om 'n brug na die verlede te slaan:

'n Afgrond skei jou van daardie verre werklikheid, dog afgronde is oorbrugbaar wanneer die pad eenmaal gevind is; 'n glaswand skei jou onverbiddelik van die wêreld wat voor jou oë uitgestrek lê, dog onder jou tastende handdruk kan dit skielik kraak en splinter soos ys (14).

Die tweede afdeling, "Aankoms", bring die konkrete uitwerking van hierdie beeld. Dit beskryf hoe 'n skrywer, saam met 'n fotograaf, op pad is na Fouriesfontein om daar die graf van die Boereheld Giel Fourie en 'n monument wat aan die Anglo-Boereoorlog gewy is, te besigtig. Hierdie besoek is deel van 'n reis deur die land op soek na gedenktekens, grafte en monumente vir 'n boek oor die Anglo-Boereoorlog. Tussen Kromburg en Donkerpoort kan hulle egter nie die afdraaipad na Fouriesfontein kry nie. Wanneer hulle verwonderd stilhou en die skrywer uit die motor klim om in die hitte van die dag te voet die dorp te gaan soek, verskuif die werklikheid skielik. As hy na 'n kort duiseling weer by sy positiewe kom, bevind hy hom in die Fouriesfontein ten tye van die AngloBoereoorlog. Nou besef hy: "[...] hy het aangekom" (26).

In die volgende afdeling "Verkenning" ondersoek die skrywer hierdie ander werklikheid waarin hy soos 'n gees rondbeweeg. Algaande kom hy tot die besef dat hy nie self oor enige vryheid van handeling beskik nie. Wat hy sien, word aan hom getoon. Niks gebeur toevallig nie. Dis sy taak om die betekenis van dit wat vir hom gewys word, te agterhaal. Slegs deur te wag en geduld te beoefen, kan uit die onsamehangende tonele en voorvalle betekenis gedistilleer word:

Hierdie verkenning is 'n langsame proses waarvan die sin en nut vir eers nie duidelik is nie; want dit is nodig om eers woord vir woord 'n hele onbekende taal aan te leer ten einde uiteindelik die gewenste frases te kan formuleer en 'n mening te kan uitspreek of 'n betekenis te ontsyfer (59).

In die laaste afdeling, "Besinning", tree die skrywer, wat soos 'n ouktoriële vertelinstansie klink, opnuut op die voorgrond. Hy dui aan dat die stemme sy skepping is. Dis die aanleiding tot 'n verdere beskouing oor die aard van die verhaalwerklikheid. Die skrywer konkludeer dat hierdie problematiek nie eintlik sy bekommernis is nie: 
Binne die vasgestelde raamwerk waarin jy hier beweeg, is àlles eg, waar en werklik, en jy vir jou part hoef geen twyfel te koester nie: dit is vir jou om waar te neem en te onthou, en vir ander om te ontleed, fout te vind, vrae te stel, en indien hulle hul geroepe mog voel, antwoorde te probeer soek. Elk het sy eie taak, of hare (242).

Die oortuigingskrag van die verhaalwêreld lê in die outentisiteit en die interne samehang daarvan. Dit word aan die kritikus oorgelaat om hieroor 'n oordeel te vel.

Die skryfaktiwiteit is egter nie van vryblywende aard nie. Uiteindelik is: " $[\ldots]$ die taak voltooi, die opdrag volvoer" (246). Die skrywer het geen keusevryheid nie, die onderwerp dring hom aan hom op. Dis sy opdrag om na die nooit gehoorde stemme uit die geskiedenis te luister. As hulle nie opgeteken word nie, gaan hulle heeltemal verlore. Wat hulle sê, vorm juis 'n onontbeerlike aanvulling tot kennis van en insig in die verlede, ondanks die feit dat al klaar soveel daaroor berig is: " $[. .$.$] dog op 'n ander vlak sou 'n mens ewe goed kan redeneer$ dat daar tot dusver nog altyd te min gesê is, soveel van wat eens hier gebeur het verdring, verswyg of ontken dat insig en begrip bykans onmoontlik geword het" (8). Om tot 'n meer volledige beeld van die verlede te kom, is hierdie versweè stemme van wesenlike belang. Verliesfontein beweeg dus soos $O p$ soek na generaal Mannetjies Mentz tromp-op teen die eensydigheid van die offisiële geskiedskrywing in. 'n Verdere parallel met Op soek na generaal Mannetjies Mentz is dat, soos Mannetjies Mentz, sowel Giel Fourie as Fouriesfontein produkte van die skrywersverbeelding is. Die geskiedenis word kreatief ontgin om tot 'n meer wesenlike vlak, wat anderkant suiwer geskiedkundige feite lê, te kan deurstoot. Ook Karel Schoeman bevestig sodoende die vitale funksie van die skrywer as delwer na die waarheid.

\subsection{Die Anglo-Boereoorlog as anti-geskiedenis}

Tog lyk dit asof Verliesfontein 'n tradisionele uitgangspunt het. Die skrywer en sy medereisiger, die fotograaf, ry dwarsdeur Suid-Afrika met die oog op die samestelling van 'n boek gewy aan Boereoorloggedenktekens. Reeds in die afdeling "Die rebel", wat nog vanuit die perspektief van die reisiger-skrywer beskryf word - ook by Coetzee is die redakteur, as verkoopsman, altyd op reis verskuif die fokus algaande van die Boereoorlogheld Giel Fourie, wie se graf hulle op Fouriesfontein wil besoek, na dominee J.J.G. Broodryk. Deur sy toedoen het Giel Fourie 'n heldestatus verwerf: "[...] sou dit te ver gaan om te sê dat dit deur die noeste arbeid van dominee Broodryk was dat jong Giel Fourie tot martelaar verhef is en tot legende en mite uitgegroei het?" (77). Met die aksentverskuiwing van Giel Fourie na die persoon wat vir sy heldestatus verantwoordelik is, val die klem in hierdie afdeling veral op die manier waarop sy dood aangewend is om die Afrikanersaak te dien. Schoeman stel hiermee die mitologiseringsproses, waardeur die Anglo-Boereoorlog en die Boereslagoffers 
in 'n aura van onkreukbaarheid, smetteloosheid en heldhaftigheid gedy het, aan die orde. Dieselfde gebeur trouens ook baie nadruklik in $O p$ soek na generaal Mannetjies Mentz.

Soos vir Mannetjies Mentz, leer die leser vir Giel Fourie nie werklik ken nie. In die roman word daar skaars aandag aan hom geskenk. Die held verskuif na die periferie, en eintlik was hy ook nie eers 'n held nie. Sy dood kom altyd onregstreeks ter sprake en word nooit in detail beskryf nie. Daar is geen enkele aanduiding dat Giel Fourie hom heldhaftig gedra het nie; die doodskoot lyk eerder na 'n ongelukkige toeval tydens 'n onbelangrike skermutseling in die Anglo-Boereoorlog.

Verliesfontein handel oor die inval van 'n Vrystaatse kommando in die Kaap in Desember 1900. In die roman word hierdie voorval nie binne 'n ruimer historiese verband gesitueer nie. Nóg vir die inval, nóg vir die AngloBoereoorlog self word daar enige verklaring gegee. Hierdeur word aan die verhaalde feite ' $n$ absolute waarde toegeken. Dis immers nie die historiese kontekstualisering wat belangrik is nie, maar net wat op Fouriesfontein self gebeur het. Van enige relativering is dan ook geen sprake nie. Die aandag gaan hoofsaaklik uit na die manier waarop die oorlog die lewens van die mense wat daarmee in aanraking gekom het, affekteer. Vir Schoeman is nie soseer die reg of verkeerd van die groot gang van die geskiedenis van belang nie, maar wel die wyse waarop die oorlogsaktiwiteite in die lewe van die individu ingryp en daardeur die loop van die geskiedenis bepaal. So het die besetting van Fouriesfontein die verdeeldheid binne die verskillende groepe waaruit die plaaslike gemeenskap saamgestel is, aangewakker wat tot 'n onherstelbare breuk gelei het:

Oor en weer deur ons klein gemeenskappie het die verdeeldheid geloop, soos loopgrawe, soos doringdraad, om nooit weer verwyder te word nie, ook nadat die oorlog verby was. [...] Oor en weer loop die doringdraad, mens van mens geskei en verdeel in hierdie onversoenbare land (233).

Ook van die besetting van Fouriesfontein word op 'n onkonvensionele manier verslag gedoen. In die eerste plek gebeur daar tydens die besetting van 'n paar weke militêr glad niks nie. Daar word nooit geveg nie en as die Engelse ontsettingstroepe opdaag, word die dorp sonder teenstand, op 'n kort skermutseling na, ontruim. Boonop is die drie persone wat verslag lewer oor wat op die dorpie gebeur het, nie regstreekse betrokkenes nie en dui hulle al drie aan dat hulle van die oorlog bitter min weet. Die drie stemme - Alice, die dogter van die Engelse magistraat, Kallie, die kruppel Afrikaanse magistraatsklerk en Miss Godby, die suster van die oorlede dokter, is nie-bevoorregte getuies. Al drie is tydens die aanwesigheid van die Boerekommando omtrent vasgevang in hulle huise omdat hulle Engels is of, in die geval van Kallie, van Engelse lojaliteite verdink word. Dat die stemme wat oor die oorlog vertel Engels is, beteken natuurlik ook dat 
die oorlogsgebeurtenisse vir die Afrikaner vanuit die invalshoek van die "vyand" benader word.

Die drie getuies vertel hulle eie verhaal lank na die afloop van die gebeure. Hulle le die nadruk daarop dat hulle die oorlog nie eintlik kan beskryf nie omdat hulle so min daarvan gesien het en skaars die feite kan onthou. Hulle verhale is, soos by Coetzee, subjektief en onsamehangend. Die eerste verteller is Alice wat saam met haar tannie op die dorp agterbly nadat haar pa, net voor die koms van die Boere, die geld en dokumente van die magistraatskantoor na veiligheid gebring het. Sy beskryf die lewe voor die inval, haar kontak met Giel Fourie en die verdeeldheid binne die klein gemeenskap wat deur die inval veroorsaak is. Die oorlog het nie goeie herinneringe vir haar ingehou nie en sy wil eintlik nie daaraan terugdink nie.

Die tweede verhaal is dié van Kallie Kleynhans. Hy berig oor sy uitgeslotenheid uit die Afrikanergemeenskap omdat hy vir die Engelse magistraat werk, oor die toenemende verdeeldheid binne die dorpie, sy vriendskap met Adam Balie, die optrede van die kommando op die dorp en sy eie skryfwerk. Na die oorlog het hy die dorp verlaat en nooit weer teruggekeer nie.

Die laaste getuie is Miss Godby. Haar verhaal fokus veral op die gebeurtenisse rondom Adam Balie, die leier van die kleurlinggemeenskap, wat weens sy proEngelse gesindheid deur die Boerekommando van ondermynende aktiwiteite verdink word. Na sy aanhouding word hy swaar gegesel en by die aftog van die Boere doodgeskiet. Schoeman het hierdie gebeure gebaseer op die geskiedenis van Abraham Esau. Self het hy hieroor 'n artikel "Die dood van Abraham Esau: ooggetuieberigte uit die besette Calvinia, 1901" (1985) gepubliseer. Vir Miss Godby is die mishandeling van Adam Balie 'n daad van onreg en van absolute boosheid: "Dit is wat ek met 'boosheid' bedoel of met 'duisternis' wanneer ek hierdie groot en gelaaide woorde gebruik: mag wat op onverantwoordelike wyse uitgeoefen word, misbruik word met die doel om te vernietig of te verwoes" (227). Die Boeremagte het hulle hieraan skuldig gemaak sodat, soos in Op soek na generaal Mannetjies Mentz, hulle ook in Verliesfontein die verteenwoordigers word van die kwade. Ook die Anglo-Boereoorlog en die optrede van die Boere word nou heeltemal ondergrawe. Die teenstelling met die Engelse stemme, en veral met Miss Godby s'n, wat van baie medemenslikheid getuig veral ten opsigte van die kleurlinggemeenskap - is baie uitgesproke.

Die gebeure rondom Adam Balie groei uit tot die kerngegewe van die roman. Ook hierdeur vind 'n belangrike aksentverskuiwing plaas. Die Anglo-Boereoorlog is nie langer 'n konflik tussen Afrikaner en Engelsman nie, maar wel een tussen die Boere en die kleurlinge. Schoeman stel die openlike rassisme van die Boerekommando en hul ongebreidelde haat jeens die kleurlingbevolking onomwonde aan die kaak. Deur die aandag vir die rasseteenstellings kry die Anglo-Boereoorlog 'n totaal ander dimensie as wat meestal die geval is. 
Buitendien het die Anglo-Boereoorlog in terme van rasseverhoudinge 'n vernietigende nawerking gehad. Omdat die rasseteenstellings in die AngloBoereoorlog op die spits gedryf is, het die rasseverhoudinge gedurende die hele twintigste eeu totaal versuur. Schoeman argumenteer dat die Anglo-Boereoorlog die gesig van Suid-Afrika fundamenteel gewysig en die verskillende rasse definitief van mekaar vervreem het. Die gegewe dat, soos by Coetzee, die daders nooit gestraf is nie, dra ook in 'n belangrike mate hiertoe by. Dis trouens uiters ironies dat Giel Fourie na die oorlog tot 'n held uitgeroep is, terwyl Adam Balie, die ware held omdat hy hom vrywillig aan die Boerekommando oorgegee het om die verdere swaarkry van sy mense te verhinder, nooit enige offisiële erkenning gekry het nie.

Soos in Op soek na generaal Mannetjies Mentz kry ook die gebeure in Verliesfontein 'n universele dimensie deurdat uitdruklik aangedui word dat nie net die Boere hulle skuldig gemaak het of maak aan ongeregtighede nie. Die oorlog is maar net een voorbeeld van die boosheid van die mens. Die aanhaling uit die gedig "The tears of heaven" van Tennyson op bladsy 48 bevestig dit. Die volledige gedig lui soos volg:

\section{The tears of heaven}

Heaven weeps above the earth all night till morn,

In darkness weeps as all ashamed to weep,

Because the earth hath made her state forlom

With self-wrought evils of unnumbered years,

And doth the fruit of her dishonour reap.

And all the day heaven gathers back her tears

Into her own blue eyes so clear and deep,

And showering down the glory of lightsome day,

Smiles on the earth's worn brow to win her if she may (Warren, 1971:840).

Dit gaan inderdaad nie om een enkele daad van onreg nie maar om al die onreg wat in die geskiedenis van die mensdom gebeur het. Wat alles nog meer ontstellend maak, is dat oënskynlik niks ooit verander nie. Miss Godby maak hieroor die volgende bedenking: "Ons het niks geleer uit wat gebeur het nie, die verdelings slegs bestendig, die verbittering verskerp" (235). Die mens lyk gedoem om die kringloop van onreg en boosheid te bly perpetueer.

\section{4. 'n Radikale hersiening}

Alhoewel Verliesfontein, as tipiese Schoemanwerk 'n heeltemal ander toonaard het as Op soek na generaal Mannetjies Mentz is die ooreenkomste tussen die twee romans opvallend. Albei romans het dieselfde basis. In al twee gevalle word die Boeremagte uiters negatief beskryf en groei hulle uit tot 'n versinnebeelding van die bose. Op soek na generaal Mannetjies Mentz het nie 'n portret van 'n heroïese generaal opgelewer nie maar van onbeteuelde wreedheid. Op Fouriesfontein moes die Boerekommando nie net die dorp prysgee nie, maar het 
hulle ook alle begrip van wettelikheid en regverdigheid verloor. Die magsposisie waarin hulle hulle bevind het, het hulle gewetenloos misbruik. Die Boeremagte word sodoende in 'n negatiewe lig geplaas. Albei romans bring 'n onthutsende korrektief op die populêre voorstelling van die Anglo-Boereoorlog. Die twee romans maak duidelik dat offisiële geskiedskrywing en verlede nie saamval nie. 'n Radikale hersiening van die geskiedenis is noodsaaklik om die verborge kant daarvan te belig. Die Boeremagte is nie langer onaantasbaar nie. Die boosheid aan Boerekant word genadeloos oopgevlek. Die Afrikaner word tot 'n konfrontasie met sy eie hart van duisternis gedwing.

Op soek na generaal Mannetjies Mentz en Verliesfontein bring 'n deurtastende demitologisering van die Anglo-Boereoorlog. Juis deur hierdie onkonvensionele terugblik op die Anglo-Boereoorlog - saam met die Groot Trek die mees prominente simbool uit die geskiedenis van die Afrikanervolk - blyk die relevansie daarvan vir die hede. Die 100-jarige herdenking van die begin van die Anglo-Boereoorlog kan deur 'n onthutsende konfrontasie met die verlede 'n noodsaaklike bydrae lewer tot 'n meer genuanseerde kyk op die verlede en tot 'n meer gebalanseerde geskiedskrywing. Immers, soos Verliesfontein dit stel: "Wie nie die verlede onthou nie, is gedoem om dit te herlewe [...]" (244). Dis seker die hoop van sowel Christoffel Coetzee as Karel Schoeman dat, ondanks die alomteenwoordigheid van die bose, hulle romans 'n aansporing inhou om lesse uit die verlede te haal.

\section{Bibliografie}

Behr, Mark. 1993. Die reuk van appels. Kaapstad : Queillerie

Brink, A.P. 1997. Die jogger. Kaapstad : Human \& Rousseau.

Coetzee, Christoffel. 1998 Op soek na generaal Mannetjies Mentz. Kaapstad : Queillerie.

De Vos, Pierre. 1994. Slegs blankes/Whites only. Bloemfontein : Kagiso.

Nieuwoudt, Stephanie. 1998. Ek probeer alternatiewe waarheid oor oorlog skets Beeld, 14 Mei.

Rautenbach, Elmari 1998. Wreedheid ken hy van kindsbeen af. In: 'Boekewêreld', bylae by Die Burger, Beeld en Die Volksblad, Julie 1

Schoeman, Karel. 1985. Die dood van Abraham Esau: ooggetuieberigte uit die besette Calvinia, 1901 Kwartaalblad van die Suid-Afrikaanse Bibliotheek 40(2):56-66, Des.

Schoeman, Karel. 1998. Verliesfontein Kaapstad : Human \& Rousseau.

Steyn, J.C 1985. Die verlore vader. Kaapstad : Tafelberg.

Warren, T Herbert 1971 Tennyson. Poems and Plays. Oxford : Oxford University Press.

Van Heerden, E. 1998 Oppas vir goedkoop nostalgie. Die Burger, Okt 1. 


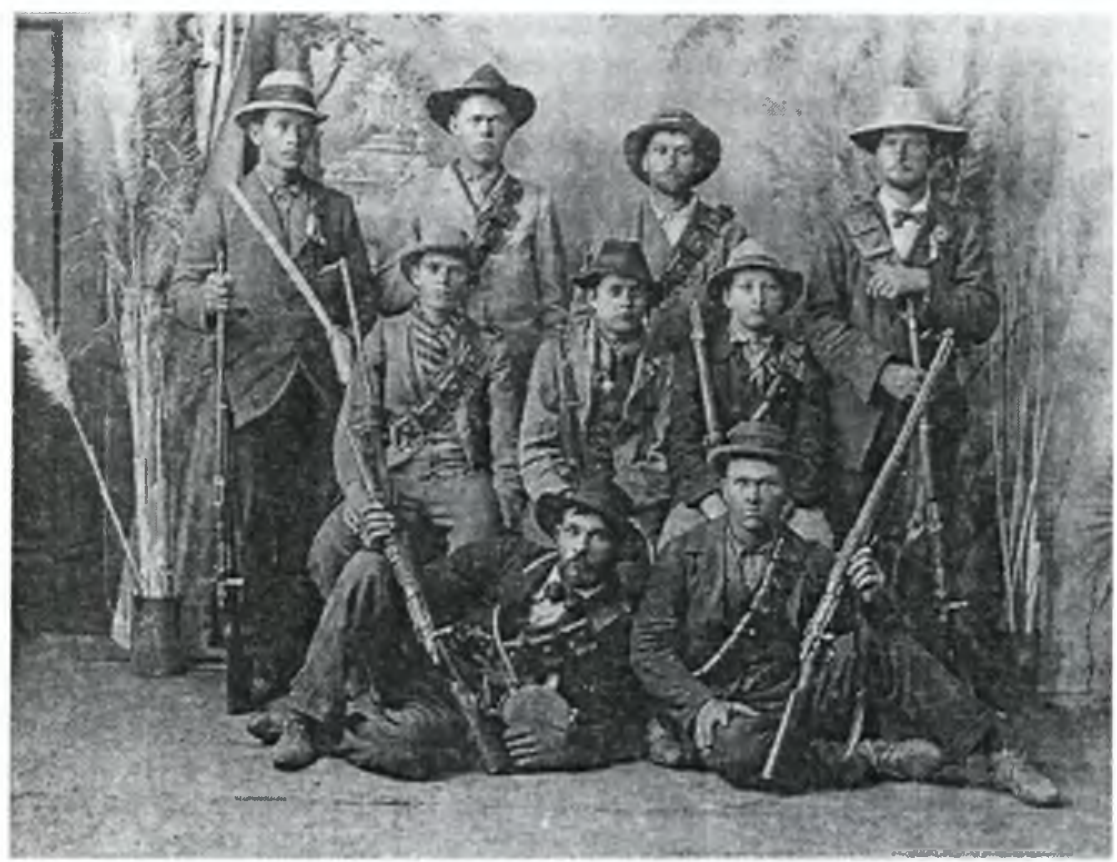

